\title{
Synthesis and Nuclear Magnetic Resonance Shielding Effect of three Triazine-Linked Porphyrin Compounds
}

\author{
Kai Wang, Shi-Tao Fu, Zhi Zhang and Zao-Ying $\mathrm{Li}^{*}$ \\ Department of Chemistry, Wuhan University, Wuhan 430072, P.R. China
}

\begin{abstract}
Três porfirinas, monômero Por I, dímero Por II e trímero Por III, foram sintetizadas através da reação de cloreto cianúrico, 5-(4-hidroxofenil)-10,15,20-trifenil porfirina e 1-fenilpiperazina. As propriedades destas porfirinas inéditas, no que diz respeito à proteção na ressonância magnética, aos acoplamentos e desdobramentos dos hidrogênios $\beta$ foram estudadas por espectroscopia de RMN de ${ }^{1} \mathrm{H}$. Os resultados mostram que os hidrogênios $\beta$ no dímero e no trímero encontram-se fortemente protegidos pelo anel porfirínico e exibem sinais com desdobramentos complicados.
\end{abstract}

Three porphyrin compounds, monomer Por I, dimer Por II and trimer Por III have been synthesized from the reaction of cyanuric chloride, 5-(4-hydroxyphenyl)-10,15,20-triphenyl porphyrin and 1-phenylpiperazine. The properties of these novel porphyrins in nuclear magnetic shielding, the shift, coupling and splitting of $\beta$ hydrogens, were studied by ${ }^{1} \mathrm{H}$ NMR spectroscopy. The results shown that $\beta$ hydrogens in dimer and trimer were shielded by porphyrin ring greatly and displayed the complicated signal peaks.

Keyword: porphyrin dimer, porphyrin trimer, synthesis, ${ }^{1} \mathrm{H}$ NMR, shielding effect

\section{Introduction}

Since porphyrins have been covalently linked to form porphyrin dimers in the 1970s, bridged bisporphyrins and other porphyrin oligomers became a focus in porphyrin chemistry because of their unique physical and chemical properties. ${ }^{1}$ In recent years, good many porphyrin dimers and oligomers have been synthesized. ${ }^{2}$ Porphyrin derivatives are studied widely as chemical sensors in supramolecular chemistry. ${ }^{3}$ Obviously, excellent photochemical properties of porphyrins have huge merits that can be used as detection units conveniently. ${ }^{4}$

Triazines have been used widely in analytical chemistry as complexation agents, in electrochemistry as multi-step redox systems and as pesticide or herbicide components in agriculture. ${ }^{5}$ In recent years, owing to its high reactivity and trifunctionality that allows easy and controlled sequential replacement of the halogens by nucleophiles, cyanuric chloride (2,4,6-trichloro-1,3,5triazine) has attracted increasing attention for potential use in the synthesis of fluorescent labeling ${ }^{6}$ and dendrimer. ${ }^{7}$ This compound has also been used to prepare porphyrin dimers and oligomers. ${ }^{8}$ In our work, we report three

*e-mail: zyliwuc@whu.edu.cn porphyrin compounds, monomer Por I, dimer Por II and trimer Por III using this triazine as a bridge. These compounds and their metal complexes are of interest in molecular recognition and catalysis. Their molecular structures are shown in Figure 1.

\section{Results and Discussion}

Three porphyrin derivatives were synthesized by sequential chloride substitution in cyanuric chloride by monohydroxylporphyrin $\mathbf{1}$ and 1-phenylpiperazine, as outlined in Scheme 1.

This sequential process was controlled by temperature and ratios of reagents. The first chlorine was substituted quickly by 1 equiv. of monohydroxylporphyrin $\mathbf{1}$ in THF in the presence of excess diisopropylethylamine (DIPEA), after $15 \mathrm{~min}$, at $0{ }^{\circ} \mathrm{C}$. This monosubstituted intermediate was used directly without purification for the synthesis of Por I, which was obtained after addition of excess 1phenylpiperazine and DIPEA and heating at $70{ }^{\circ} \mathrm{C}$ for $20 \mathrm{~h}$. The yield was $62 \%$ after purification and recrystallization. The porphyrin dimer was synthesized from the same monosubstituted intermediate, to which 1 equiv. of 1 was added with excess of DIPEA. After $24 \mathrm{~h}$ stirring at room temperature, addition of excess 


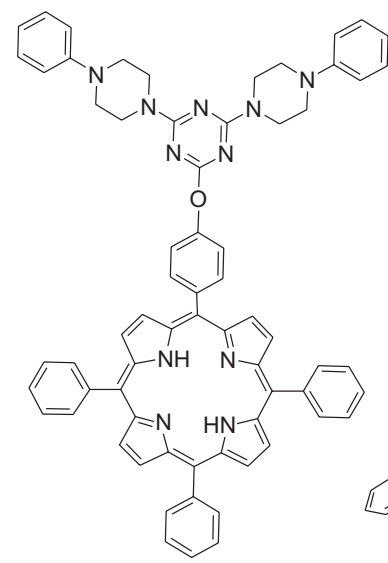

Por I

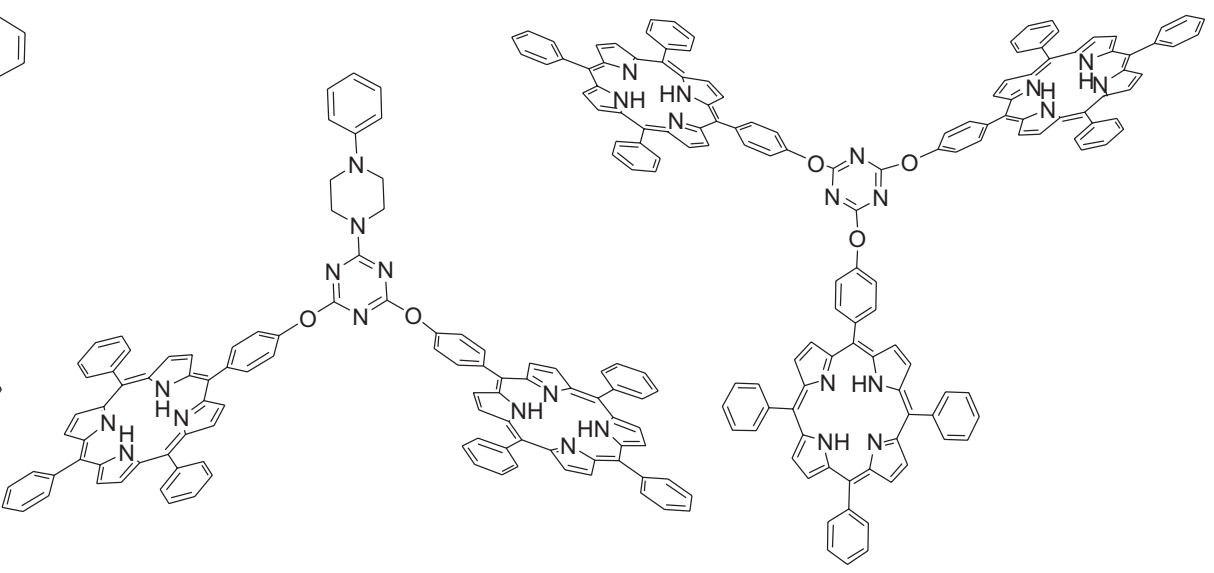

Por II

Por III

Figure 1. Chemical structure of monomer Por I, dimer Por II and trimer Por III.

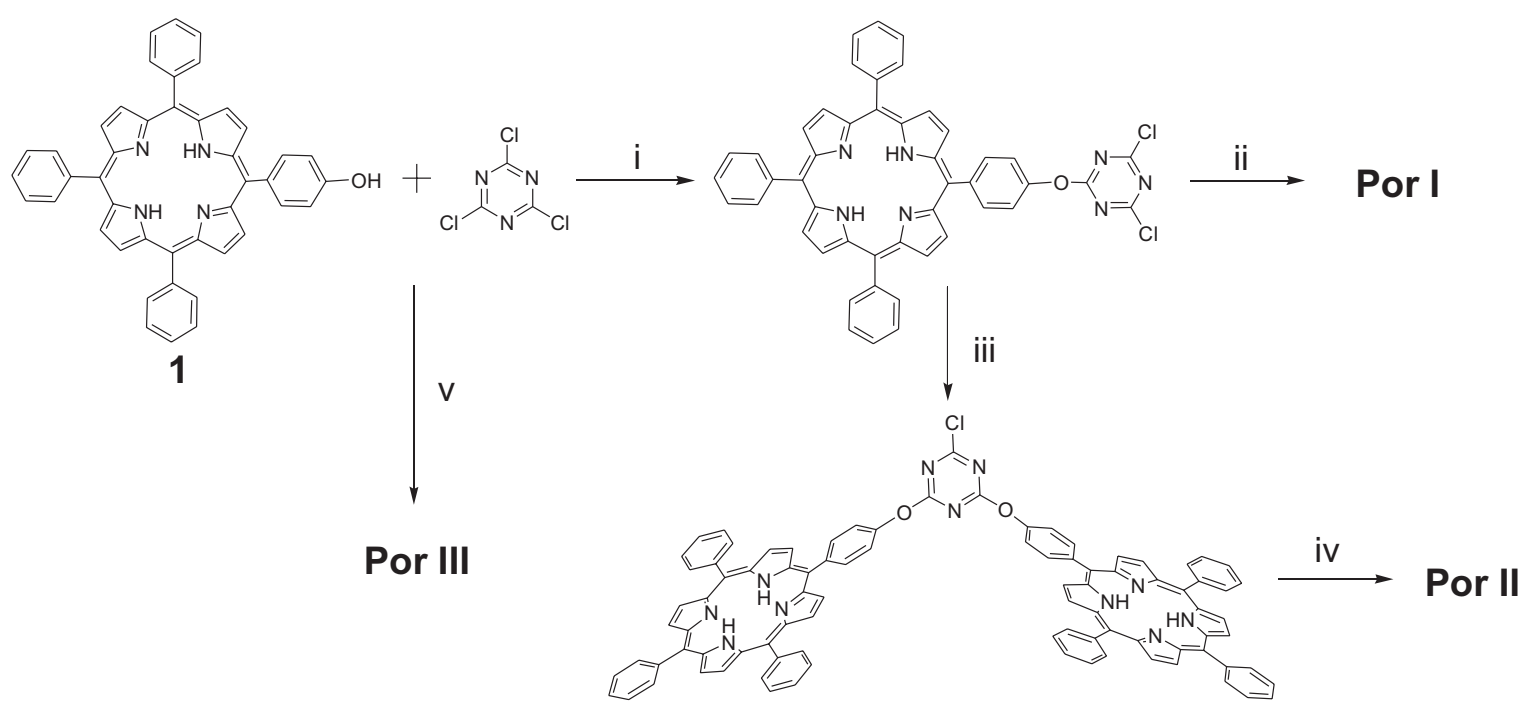

$\mathrm{i}:$ THF, DIPEA, $0{ }^{\circ} \mathrm{C}, 15 \mathrm{~min}$ ii : $\left[_{\mathrm{H}}^{\mathrm{Ph}}\right.$, DIPEA, $70^{\circ} \mathrm{C}, 20 \mathrm{~h}$ iii: $p$-hydroxyphenylporphyrin 1, DIPEA, r.t., $24 \mathrm{~h}$ iv: $\left[\begin{array}{c}N_{N}^{n} \\ \mathrm{H}\end{array}\right]$, DIPEA, $70^{\circ} \mathrm{C}, 5 \mathrm{~h} \quad$ v: THF, DIPEA, $70^{\circ} \mathrm{C}, 40 \mathrm{~h}$

Scheme 1. Synthetic route to Por I, Por II and Por III.

1-phenylpiperazine and heating at $70{ }^{\circ} \mathrm{C}$ for $5 \mathrm{~h}$ led to Por II in $42 \%$ yield, after purification. Porphyrin trimer Por III was synthesized directly by the reaction of cyanuric chloride with excess 1 at $70{ }^{\circ} \mathrm{C}$ for $40 \mathrm{~h}$. This compound was obtained in $25 \%$ yield after purification and recrystallization. This relatively poor yield, compared to the other products is attributed to the huge steric effect.

Attempts to synthesis Por II directly, as described for Por III, i.e. by reaction of 2 equiv. of $\mathbf{1}$ with 1 equiv. of cyanuric chloride to prepare the disubstituted intermediate were not successful. The first triazine chlorine being very reactive at room temperature, the result of this reaction was complicated and incomplete for $\mathbf{1}$.

${ }^{1} \mathrm{H}$ NMR spectroscopy was used to identify the three porphyrin targets and the corresponding spectra are shown in Figure 2. Complicated shielding effect on hydrogen of $\beta$-position of porphyrin was observed.

The chemical shifts and coupling constants (see Experimental) of $\beta-\mathrm{H}$ in Por I were similar to those of common tailed porphyrins. ${ }^{9}$ The $\beta$ hydrogens were split 
into two unsymmetrical doublets in a 1:3 intensity ratio. However, the $\beta-\mathrm{H}$ in Por II and Por III gave four doublet peaks. For Por II, the intensity ratio of the four peaks was $1: 1: 1: 1$, and each $a, b, c$ and $d$ positions of $\beta-\mathrm{H}$ included four protons (Figure 2). In the dimeric porphyrin molecule Por II, $\beta$ protons were shifted upfield contrasting with the monomer, which was caused by shielding of the other porphyrin ring in the molecule. With increasing distance to the center of the molecule, the $\beta$ hydrogens upfield shift became much larger.

The spectrum of Por III was similar to that of the dimer, and exhibited six protons in $a$ position, and six in $b$ position, both appearing as doublets. In this structure, the shielding effect of the porphyrin ring became much stronger, the peaks at $d$ position being shifted to $\delta 8.28$, at even higher field than the benzene ortho-H (at $\delta$ 8.38). The chemical shifts of the $\beta-\mathrm{H}$ of the three porphyrins are summarized in Table 1.

In summary, we have described the synthesis of three novel triazine-linked porphyrins and observed the shielding effect of porphyrin ring current on the â protons. Further work is being carried out on the recognition properties of these porphyrin compounds and their metal complexes.

\section{Experimental}

\section{General Procedures}

5-(4-Hydroxyphenyl)-10,15,20-triphenyl porphyrin $\mathbf{1}$ was synthesized according to literature ${ }^{10}$ method. Cyanuric chloride and 1-phenylpiperazine were used directly without further purification. All solvents used for reactions or purification were dried according to standard procedures. Chromatographic separations were performed using silica gel G (200-300 mesh, Qingdao, China).

All UV-visible spectra were obtained on a Shimadzu 1601 spectrophotometer. Proton NMR spectra were measured using a Varian Mercury-VX 300 spectrometer, chemical shifts $(\delta)$ were referenced to internal tetramethyl silane (TMS). The element analyses were measured with a Finnigan FLASH 1112 SERIES EA. Mass spectra were obtained on a TSQ 7000 instrument.

For ${ }^{1} \mathrm{H}$ NMR data, $\mathrm{Ph}_{\mathrm{o}}, \mathrm{Ph}_{\mathrm{m}}$ and $\mathrm{Ph}_{\mathrm{p}}$ indicate corresponding ortho- $\mathrm{H}$, meta-H and para-H of 10, 15, 20-triphenyl in porphyrin ring. $\mathrm{Ph}_{\mathrm{o}}{ }^{1}$ and $\mathrm{Ph}_{\mathrm{m}}{ }^{1}$ indicate corresponding ortho- $\mathrm{H}$ and meta- $\mathrm{H}$ of 5-phenyl in porphyrin ring. $\mathrm{Ph}_{\mathrm{o}}{ }^{2}$, $\mathrm{Ph}_{\mathrm{m}}{ }^{2}$ and $\mathrm{Ph}_{\mathrm{p}}{ }^{2}$ indicate corresponding ortho- $\mathrm{H}$, meta- $\mathrm{H}$ and para- $\mathrm{H}$ of phenyl which link to piperazine.

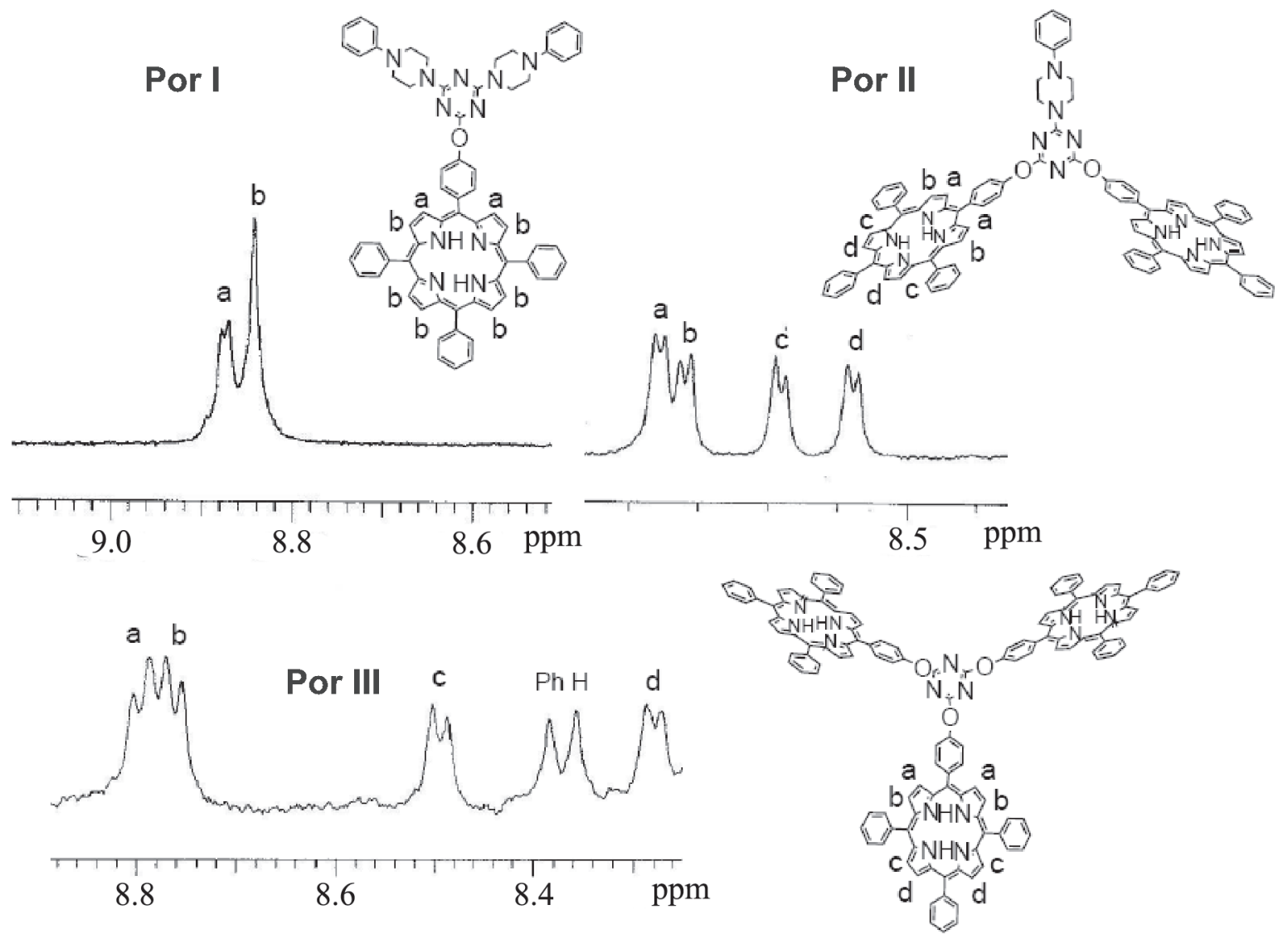

Figure 2. Shifts and compling of $\beta$ hydrogens of: Por I, Por II and Por III. 
Table 1. The chemical shifts of $\beta$ protons of porphyrins, Por I, Por II and Por III

\begin{tabular}{lcccc}
\hline & $a$ & $b$ & $c$ & $d$ \\
\cline { 2 - 5 } Por I & $8.88,2 \mathrm{H}$ & $8.85,6 \mathrm{H}$ & - & - \\
Por II & $8.86,4 \mathrm{H}$ & $8.81,4 \mathrm{H}$ & $8.67,4 \mathrm{H}$ & $8.57,4 \mathrm{H}$ \\
Por III & $8.80,6 \mathrm{H}$ & $8.77,6 \mathrm{H}$ & $8.50,6 \mathrm{H}$ & $8.28,6 \mathrm{H}$ \\
\hline
\end{tabular}

\section{Synthesis of Por I}

To a solution of monohydroxylporphyrin $1(50 \mathrm{mg}$, $0.08 \mathrm{mmol})$ in $\mathrm{THF}(5 \mathrm{~mL})$ at $0{ }^{\circ} \mathrm{C}$ was added cyanuric chloride (14.6 mg, $0.08 \mathrm{mmol}$ ) and diisopropylethylamine (DIPEA, 2 drops, about $30 \mathrm{mg}, 0.23 \mathrm{mmol}$ ), and the mixture was stirred for $15 \mathrm{~min}$. After withdrawing ice bath, the solution was stirred for $10 \mathrm{~min}$ at room temperature. Then, to the solution was added DIPEA ( 2 drops) and excess 1-phenylpiperazine ( $51.5 \mathrm{mg}, 0.32 \mathrm{mmol}$ ), and was stirred at $70{ }^{\circ} \mathrm{C}$ for $20 \mathrm{~h}$. The mixture was poured into water and the precipitate was collected, chromatographed on a column of silica gel using chloroform as eluent. The second red band was collected and recrystallized from a mixture of chloroform and petroleum ether (bp $60-90{ }^{\circ} \mathrm{C}$ ). Por I was then obtained and dried in vacuum. Yield, (51.2 mg, 62\%). (Found: C, 78.20; H, 5.41; N, 14.90. for $\left.\mathrm{C}_{67} \mathrm{H}_{55} \mathrm{~N}_{11} \mathrm{O}: \mathrm{C}, 78.11 ; \mathrm{H}, 5.38 ; \mathrm{N}, 14.96 \%\right) ; \lambda_{\max } / \mathrm{nm}[\mathrm{THF}$, $\left.\log \left(\varepsilon / \mathrm{dm}^{3} \mathrm{~mol}^{-1} \mathrm{~cm}^{-1}\right)\right]: 647$ (3.58), 590 (3.67), 550 (3.84), 515 (4.19), 419 (5.46); ${ }^{1} \mathrm{H}-\mathrm{NMR}\left(300 \mathrm{MHz}, \mathrm{CDCl}_{3}\right.$ ): $\delta$ 8.88-8.85 ( $\mathrm{m}, 8 \mathrm{H}$, pyrrole $\mathrm{H}$ ), 8.23-8.20 (complex $\mathrm{m}$, $8 \mathrm{H}, \mathrm{Ph}_{\mathrm{o}}$ and $\mathrm{Ph}_{\mathrm{o}}{ }^{1} \mathrm{H}$ ), 7.77-7.75 (complex $\mathrm{m}, 9 \mathrm{H}, \mathrm{Ph}_{\mathrm{m}}$ and $\left.\mathrm{Ph}_{\mathrm{p}} \mathrm{H}\right), 7.60\left(\mathrm{~d}, 2 \mathrm{H}, J\right.$ 8.7, $\left.\mathrm{Ph}_{\mathrm{m}}{ }^{1} \mathrm{H}\right), 7.30$ (t, 4H, $J$ 7.8, $\left.\mathrm{Ph}_{\mathrm{m}}^{\mathrm{p}}{ }^{2} \mathrm{H}\right), 7.00\left(\mathrm{~d}, 4 \mathrm{H}, J\right.$ 7.8, $\left.\mathrm{Ph}_{\mathrm{o}}{ }^{2} \mathrm{H}\right), 6.92(\mathrm{t}, 2 \mathrm{H}, J 7.2$, $\mathrm{Ph}_{\mathrm{p}}{ }_{\mathrm{p}} \mathrm{H}$ ), 4.06 (s, 8H, Ph-N-CH $), 3.28$ (s, 8H, Ph-N-C-CH $)$, -2.77 (s, 2H, pyrrole N-H); FAB-MS $\left(\mathrm{M}^{+}\right)$Found: 1030. Calc. for $\mathrm{C}_{67} \mathrm{H}_{55} \mathrm{~N}_{11} \mathrm{O}: 1030.23$.

\section{Synthesis of Por II}

To a solution of monohydroxylporphyrin $\mathbf{1}(50 \mathrm{mg}, 0.08$ $\mathrm{mmol})$ in THF $(5 \mathrm{~mL})$ at $0{ }^{\circ} \mathrm{C}$ was added cyanuric chloride (14.6 $\mathrm{mg}, 0.08 \mathrm{mmol}$ ) and diisopropylethylamine (DIPEA, 2 drops, about $30 \mathrm{mg}, 0.23 \mathrm{mmol}$ ), and the mixture was stirred for $15 \mathrm{~min}$. After withdrawing ice bath, the solution was stirred at room temperature for $10 \mathrm{~min}$. Then, the solution was added to DIPEA (2 drops) and monohydroxylporphyrin $1(50 \mathrm{mg}, 0.08 \mathrm{mmol})$, and was stirred at room temperature for $24 \mathrm{~h}$. To the resulting solution was added excess 1-phenylpiperazine $(25.7 \mathrm{mg}, 0.16 \mathrm{mmol})$, and the solution was reacted at $70{ }^{\circ} \mathrm{C}$ for $5 \mathrm{~h}$. With similar purification method of Por I (chloroform and methanol $(v / v=100: 0.5)$ as eluent), Por II afforded (50.4 mg, 42\%).
(Found: C, 80.87; $\mathrm{H}, 4.75 ; \mathrm{N}, 12.20$. for $\mathrm{C}_{101} \mathrm{H}_{71} \mathrm{~N}_{13} \mathrm{O}_{2}: \mathrm{C}$, 80.94; H, 4.77; N, $12.15 \%) ; \lambda_{\max } / \mathrm{nm}\left[\mathrm{THF}, \log \left(\varepsilon / \mathrm{dm}^{3} \mathrm{~mol}^{-1}\right.\right.$ $\left.\mathrm{cm}^{-1}\right)$ ]: 647 (3.67), 591 (3.78), 548 (3.96), 514 (4.29), 417 (5.59); ${ }^{1} \mathrm{H}-\mathrm{NMR}\left(300 \mathrm{MHz}, \mathrm{CDCl}_{3}\right): \delta 8.86-8.57(\mathrm{~m}, 16 \mathrm{H}$, pyrrole $\mathrm{H}$ ), 8.32-8.23 (complex $\mathrm{m}, 10 \mathrm{H}, \mathrm{Ph}_{\mathrm{o}}$ and $\mathrm{Ph}_{0}{ }^{1} \mathrm{H}$ ), 7.81-7.79 (m, 12H, $\mathrm{Ph}_{\mathrm{m}} \mathrm{H}$ ), 7.70-7.58 (complex m, 10H, $\mathrm{Ph}_{\mathrm{o}}$ and $\left.\mathrm{Ph}_{\mathrm{m}}{ }^{1} \mathrm{H}\right), 7.45$ (t, 6H, J 7.5, $\mathrm{Ph}_{\mathrm{p}} \mathrm{H}$ ), 7.36 (t, 2H, $J$ 7.5, $\left.\mathrm{Ph}_{\mathrm{m}}{ }^{2} \mathrm{H}\right), 7.05$ (d, 2H, J 7.8, $\left.\mathrm{Ph}_{\mathrm{o}}{ }^{2} \mathrm{H}\right), 6.97$ (t, $1 \mathrm{H}, J 6.3$, $\mathrm{Ph}_{\mathrm{p}}{ }^{2} \mathrm{H}$ ), 4.20 (s, 4H, Ph-N-CH $), 3.40$ (s, 4H, Ph-N-C- $\mathrm{CH}_{2}$ ), -2.84 (s, 4H, pyrrole N-H); FAB-MS (M+) Found: 1498. Calc. for $\mathrm{C}_{101} \mathrm{H}_{71} \mathrm{~N}_{13} \mathrm{O}_{2}: 1498.73$.

\section{Synthesis of Por III}

To a solution of monohydroxylporphyrin 1 (75 mg, $0.12 \mathrm{mmol})$ in THF $(10 \mathrm{~mL})$ was added cyanuric chloride (7.3 mg, $0.04 \mathrm{mmol}$ ) and diisopropylethylamine (DIPEA, 2 drops, about $30 \mathrm{mg}, 0.23 \mathrm{mmol}$ ), and then the mixture was stirred at $70{ }^{\circ} \mathrm{C}$ for $40 \mathrm{~h}$. Using same purification method of Por II, Por III was afforded (20 mg, 25\%). (Found: C, 82.34; H, 4.41; N, 10.73. for $\mathrm{C}_{135} \mathrm{H}_{87} \mathrm{~N}_{15} \mathrm{O}_{3}$ : C, $82.42 ; \mathrm{H}, 4.46 ; \mathrm{N}, 10.68 \%) ; \lambda_{\max } / \mathrm{nm}\left[\mathrm{THF}, \log \left(\varepsilon / \mathrm{dm}^{3}\right.\right.$ $\left.\mathrm{mol}^{-1} \mathrm{~cm}^{-1}\right)$ ]: 648 (3.79), 590 (3.92), 550 (4.06), 516 (4.42), 419 (5.70); ${ }^{1} \mathrm{H}-\mathrm{NMR}\left(300 \mathrm{MHz}, \mathrm{CDCl}_{3}\right): \delta 8.80(\mathrm{~d}, 6 \mathrm{H}, J$ 4.8, pyrrole $\mathrm{H}$ ), 8.77 (d, $6 \mathrm{H}, J 4.8$, pyrrole $\mathrm{H}$ ), 8.50 (d, $6 \mathrm{H}, J 4.8$, pyrrole $\mathrm{H}), 8.38$ (d, 9H, $\left.J 8.1, \mathrm{Ph}_{\mathrm{o}} \mathrm{H}\right), 8.28$ (d, $6 \mathrm{H}, J$ 4.8, pyrrole H), 8.23 (d, 9H, $J$ 8.1, $\mathrm{Ph}_{\mathrm{o}} \mathrm{H}$ ), 7.77 7.74 (complex m, 27H, $\mathrm{Ph}_{\mathrm{m}}$ and $\left.\mathrm{Ph}_{\mathrm{p}} \mathrm{H}\right), 7.38(\mathrm{~d}, 6 \mathrm{H}, J$ 7.8, $\left.\mathrm{Ph}_{\mathrm{o}}{ }^{1} \mathrm{H}\right), 7.11\left(\mathrm{~d}, 6 \mathrm{H}, J\right.$ 7.8, $\left.\mathrm{Ph}_{\mathrm{m}}{ }^{1} \mathrm{H}\right),-2.91(\mathrm{~s}, 6 \mathrm{H}$, pyrrole N-H); FAB-MS $\left([\mathrm{M}+\mathrm{H}]^{+}\right)$Found: 1968. Calc. for $\mathrm{C}_{135} \mathrm{H}_{87} \mathrm{~N}_{15} \mathrm{O}_{3}:$ 1967.23.

\section{Ackonwledgments}

We acknowledge the financial support from the National Natural Science Foundation of China (Grant, CN 20672082).

\section{References}

1. Schwarz, F. P.; Gouterman, M.; Muljiani, Z.; Dolphin, D. H.; Bioinorg. Chem. 1972, 2, 1; Takashi, H.; Masanori, N.; Toshihiro, A.; Hisanobu, O.; Tetrahedron Lett. 1997, 38 , 1603; Kim, J. O.; Liu, H. Y.; Hu, X. M.; Ying, X.; Liu, Y.; Huang, J.; Huang, J. W.; Ji, L. N.; Tian, X.; Yang, L.; Zhu, Q. X.; Chem. J. Chin. Univ. 1999, 20, 849; Lee, Y. A.; Jin, B.; Park, T.; Song, R.; Kim, S. K.; Biophys. Chem. 2004, 111,63 .

2. Tomohiro, Y.; Satake, A.; Kobuke, Y.; J. Org. Chem. 2001, 66, 8442; Takase, M.; Ismael, R.; Murakami, R.; Ikeda, M.; Kim, D.; Shinmori, H.; Furuta, H.; Osuka, A.; Tetrahedron Lett. 2002, 
43, 5157.; Fujihara, T.; Tsuge, K.; Sasaki, Y.; Kaminaga, Y.; Imamura, T.; Inorg. Chem. 2002, 41, 1170; Kieran, A. L.; Bond, A. D.; Belenguer, A. M.; Sanders, J. K. M.; Chem. Commun. 2003, 2674; Yagi, S.; Ezoe, M.; Yonekura, I.; Takagishi, T.; Nakazumi, H.; J. Am. Chem. Soc. 2003, 125, 4068.

3. Arnold, D. P.; Blok, J.; Coord. Chem. Rev. 2004, 248, 299; Simonneaux, G.; Le Maux, P.; Coordin. Chem. Rev, 2002, 228, 43; Burns, D. H.; Carper, W. R.; THEOCHEM-J. Mol. Struct. 2004, 711, 149; Rein, R.; Gross, M.; Solladié, N.; Chem. Commun. 2004, 1992.

4. Zhang, Y.; Yang, R. H.; Liu, F.; Li, K. A.; Anal. Chem. 2004, 76, 7336; Mizutani, T.; Wada, K.; Kitagawa, S.; J. Am. Chem. Soc. 1999, 121, 11425; Gulino, A.; Bazzano, S.; Mineo, P.; Scamporrino, E.; Vitalini, D.; Fragala, I.; Chem. Mater. 2005, 17,521 .
5. Giacomelli, G.; Porcheddu, A.; De Luca, L.; Curr. Org. Chem. 2004, 8, 1497.

6. Su, M. H.; Ma, H. M.; Ma, Q. L.; Wang, Z. H.; Xiong, S. X.; Liang, S. C.; Anal. Chim. Acta. 2001, 426, 51; Ma, H. M.; Nie, L.H.; Xiong, S. X.; Supramol. Chem. 2004, 16, 311.

7. Lupton, J. M.; Hemingway, L. R.; Samuel, I. D. W.; Burn, P. L. J.; J. Mater. Chem. 2000, 10, 867; Lebreton, S.; Newcombe, N.; Bradley, M.; Tetrahedron 2003, 59, 10213.

8. Carofiglio, T.; Varotto, A.; Tonellato, U.; J. Org. Chem. 2004, 69,8121 .

9. Montanari, F.; Penso, M.; Quici, S.; Vigano, P.; J. Org. Chem. 1985, 50, 4888.

10. Huang, S. Q.; Sun, L. M; Ye, Q.; Chem. J. Chin. Univ. 1983, 4, 381.

Received: October 16, 2006

Web Release Date: July 24, 2007 